\title{
Infiltration Capacity in Flood Mitigating Jakarta
}

\author{
Elsa Herda Adeline ${ }^{1}$, Hayati Sari Hasibuan ${ }^{2}$ and Setyo Sarwanto Moersidik ${ }^{3}$ \\ \{ $\underline{\text { elsaherda@gmail.com }}{ }^{1}, \underline{\text { hayati.hasibuan@ui.ac.id }{ }^{2}}$ and ssarwanto@eng.ui.ac.id ${ }^{3}$ \} \\ Environmental Science Study Program, Postgraduate Program Universitas Indonesia ${ }^{1,2,3}$
}

\begin{abstract}
Green Open Space (GOS) with hydrological function is expected to assist minimize Jakarta floods. Rainfall data calculated using Ffolliott equation to get the volume and velocity of water that infiltrates. The determination of the GOS locations are based on minimum 1 ha wide; represent different groundwater vulnerability classifications based on Ground Water Level (GWL) 0-40 meters; represents a different classification of Jakarta Groundwater Availability and Utilities Analysis; not include PAM Jaya service coverage areas; include in the Protected Green Open Zone, City Forest Zone, City Park Zone, Green Lane Zone (Green Lane Sub Zone only) and Recreational Green Zone; existing GOS is not as a road median.The highest infiltration based on GWL 0-40 meters located at the Poor category and based on types of the land ecoregion found in Plain sandbank beach - Intersandbank valley and Fluvio-marin Plain.
\end{abstract}

Keywords: Green Open Space, Infiltration, Jakarta, Land ecoregion, Groundwater

\section{Introduction}

Green Open Space (GOS) in urban areas has an ecological function as a place to save water reserves that are influential in reducing the heat island situation [1] and also the sustainability of the city, which have a role to maintain the hydrological cycle and water quality[2]. Ecological, economic and social functions are functions that are occupied by GOS which is a green area with benefits for welfare in life, health and contributes to the sustainability of an area[3].

A growing population of the people living in cities until it is estimated that it reaches two-thirds of the world's inhabitant in 2050[4] results in increased land-use change. The increased impermeable surface will inversely proportional to the ability of infiltration thereby increasing the tendency for flooding[1]. These conditions can be the significance basis of maintaining GOS with high soil permeability to delay runoff water so that it also has an effect on reducing urban flooding[5].

Comparison within zoning plans in the Detail Spatial Planning and Zoning Regulations (RDTRPZ)[6] shows 48\% are Settlement Zones, 14\% Commercial and Office Zones, 7\% Industrial Zones, 11\% Blue Open Spaces (BOS), Government and Social and Public Facilities Zones 7\% and $13 \%$ GOS (without GOS buffer calculations). The other study[7] asserted that the percentage of stipulated GOS zoning was $11.7 \%$ (7,749.36 ha) with realized GOS conditions 473.94 ha which 
is equivalent to $5.31 \%$ of the total area. However, based on information from the Jakarta Forestry Agency, GOS that already realized was only was $4.65 \%(3,080.89)$ ha. In more detail, Figure 1 shows the design position of the GOS that contained in RDTR-PZ.

Based on geomorphology that shows in Figure 2[8] there are six types of the land ecoregion in Jakarta:

1. Muddy Tidal Plains, which is formed by the marine process and stretches along the coastline with material as generally fine-textured.

2. Plain sandbank beach - Inter-sandbank valley. These are a pile of sand that extends along the coastline with common material is sand.

3. Swamp Plains, this formed from the results of the fluvial deposition process that leave a plain with small basins that are randomly scattered.

4. Flood Plain, the plain that formed around the river channel and always flooded especially in the rainy season.

5. Fluvio-marin Plain, this plain is usually a little far from the coastline or behind muddy tidal plains and suitable for the development of aquaculture ponds. It is a plain that occurs as a result of marine activity namely a lagoon and then material alluvium covering it[9].

6. Fluvio-volcanic Plain. This plain is predominantly derived from the Pangrango volcano and the Salak volcano located in the southern part Jakarta with the landform's character is high accessibility due to flat relief, suitable for the development of agricultural cultivation and other developed areas.

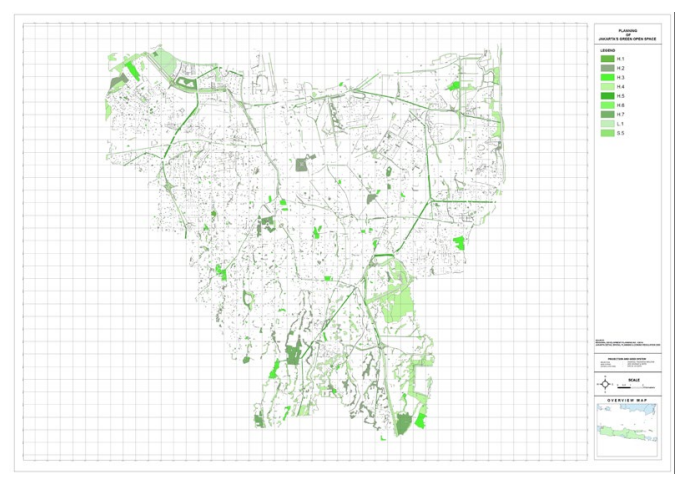

Figure 1. GOS Planning Map

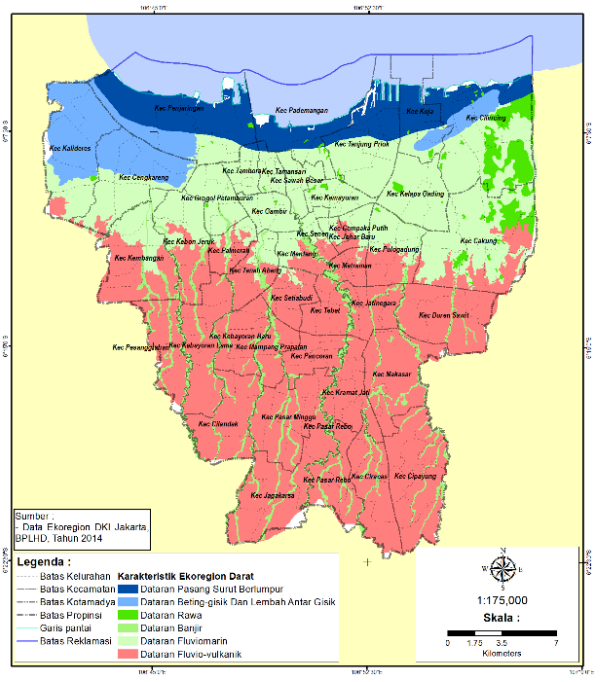

Figure 2. Map of Jakarta's land ecoregion types 
Being in a swamp area which is mostly below sea level[10] and also on low and flat alluvial land is characteristic of the city of Jakarta. Based on that facts if flooding occurs especially in the rainy season it has not become surprisingly. That condition not only has the potential to cause inundation which results in flood events but in the north area of Jakarta land subsidence also results in seawater intrusion[11]. The decreasing groundwater level is one of the things that causes land subsidence. There are four kinds of land subsidence that occurred in Jakarta[12], namely the decrease due to the burden of construction, natural consolidation of alluvial soils, tectonic disasters and groundwater extraction.

Flood and inundation events that hit the city of Jakarta routinely are the main issues that form the basis of spatial planning. The city of Jakarta is downstream from several rivers that flow into Jakarta Bay, so that surface runoff from upstream will overload the drainage system in Jakarta City. Based on this, the presence of GOS with hydrological function is expected to assist minimize Jakarta floods. From data published in 2015[13] in the five regions of Jakarta in 702 affected hamlet, there is still standing water with a height of $>150 \mathrm{~cm}$. With the development of urban development, the swamp draining activities further enhance the potential for flooding.

The role of GOS in the hydrological aspect is to increase resistance to the risk of drought and flooding[15]. In terms of drought, especially clean water sources, from 2000 to 2015 Jakarta Water Supply Company (PAM Jaya) can only serve 35\%[16] of the total population (the difference between total water sales and total water needs), while PAM Jaya states that the percentage of service coverage has reached $60 \%[17]$. Based on this condition the Government cannot prohibit groundwater extraction especially for areas outside the PAM Jaya service area. An analysis related to the presence of groundwater, classified the Jakarta groundwater crisis area based on physical, social and policy variables become into 3 (three) groups conditions[18] of Vulnerable, Prone and Crisis Groundwater. Beside of that refer to aquifer Ground Water Level (GWL) 0-40 meters, Jakarta classified into 5 categories (see Figure 4)[19]:

1. Very good (decrease GWL: -(5-10) meters Above Sea Level (ASL))

2. Good (GWL contour $(-5)-0$ ASL)

3. Moderate (GWL contour $0-25$ ASL)

4. Poor (GWL contour $25-50$ ASL)

5. Extremely poor (GWL contour $>50$ ASL) 


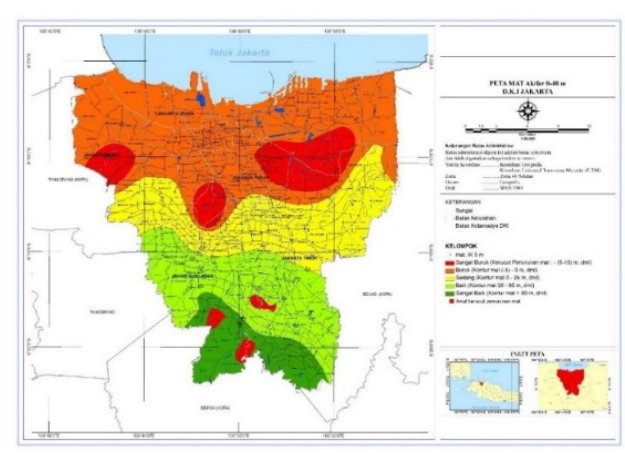

Figure 3. Map of Jakarta aquifer Ground Water Level (GWL) 0-40 meters

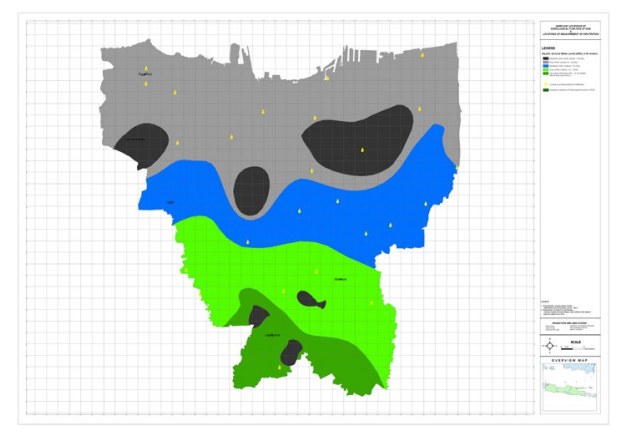

Figure 4. GOS Sampling Location to Infiltration Measurement Point

The Ground Water Conservation Office (GWCO) under The Ministry Of Energy and Mineral Resources provides data on infiltration level[20] measured at several locations in units of $\mathrm{cm} / \mathrm{sec}$. (see Figure 4).

\section{Methods}

This study was based on the approach of a quantitative method used to measure the amount and velocity of infiltration in GOS. It is expected could be determining the planning of potential GOS locations regarding infiltration based on types of the land ecoregion and aquifer groundwater level. When determining the number of GOS samples, the sampling technique used is the Stratified Random Sampling method. The determination of the GOS locations are based on the following criteria:

1. At least 1 ha wide[21]

2. Represent different groundwater vulnerability classifications based on Ground Water Level (GWL) 0-40 meters[19]

3. Represents a different classification of Jakarta Groundwater Availability and Utilities Analysis[18]

4. Location does not include PAM Jaya service coverage areas[17]

5. The location is in the Protected Green Open Zone, City Forest Zone, City Park Zone, Green Lane Zone (Green Lane Sub Zone only) and Recreational Green Zone[6]

6. The existing GOS is not as a road median.

\subsection{Data analysis technique}

Techniques in analyzing data in this study consist of spatial analysis with Geographic Information Systems (GIS) and descriptive analysis of hydrology with the Ffolliot method. Various information on the world that is complex and in the form of digital information can be derived by GIS and produce digital maps or attribute data as information produced[7]. To analyze 
the frequency of rainfall, which refers to how to analyze rainfall in urban drainage[22], a minimum of 10 years of hydrological data is required. Calculating infiltration, rainfall data is needed so that this study will use rainfall data at Jakarta's Meter III Kemayoran station in a period of 10 years. The data will be used in calculating the volume and velocity of water that infiltrates into the ground through an empirical approach to the scope of free aquifers by calculating groundwater potential using the Ffolliott[23] equation (1980).

$$
\mathrm{R}=(\mathrm{P}-\mathrm{ET}) \cdot \mathrm{Ai}(1-\mathrm{Cro})
$$

$$
\begin{array}{cl}
\mathrm{R} & : \text { Infiltration discharge }\left(\mathrm{m}^{3} / \text { second }\right) \\
\mathrm{P} & : \text { Rainfall }(\mathrm{mm} / \text { year }) \\
\mathrm{ET} & : \text { Evapotransiration }(\mathrm{mm} / \text { year }) \\
\mathrm{Ai} & : \text { Area }\left(\mathrm{m}^{2}\right) \\
\mathrm{Cro} & : \text { Surface runoff coefficient }
\end{array}
$$

To find the value of evapotranspiration, the Thornthwaite and Mather (1957) equation is used as follows:

$$
\begin{aligned}
& \mathrm{PET}=1.6\left(\frac{L}{12}\right)\left(\frac{N}{30}\right)\left(\frac{10 T a}{\mathrm{I}}\right)^{\alpha} \\
& \alpha=\left(6.75 \times 10^{-7}\right) \mathrm{I}^{3}-\left(7.71 \times 10^{-5}\right) \mathrm{I}^{2}-\left(1.792 \times 10^{-2}\right) \mathrm{I}+0.4923 \\
& \mathrm{I}=\sum_{i=1}^{12}\left(\frac{T a i}{5}\right)^{1,514}
\end{aligned}
$$

A popular method used in calculating the runoff coefficient is called the "Kenessey Method" in which the number of partial coefficients is based on vegetation, slope and soil permeability[24]. If there are various land uses with different $C$ in one watershed, then $C$ can be obtained by taking into account the three factors with each coefficient listed in Table 1. 
Table 1. Runoff coefficient for various types of ground cover

\begin{tabular}{|l|l|l|l|l|l|}
\hline \multicolumn{5}{|c|}{ Runoff Coefficient Cr $=\mathbf{C t}+\mathbf{C s}+\mathbf{C v}$} \\
\hline \multicolumn{2}{|c|}{ Topography, Ct } & \multicolumn{2}{c|}{ Soil, Cs } & \multicolumn{2}{c|}{ Vegetation, Cv } \\
\hline Flat $(<1 \%)$ & 0.03 & Sand and gravel & 0.04 & Forest & 0.04 \\
Bumpy $(1-10 \%)$ & 0.08 & Sandy loam & 0.08 & Agriculture & 0.11 \\
Hills (10-20\%) & 0.16 & Clay and Silt & 0.16 & Meadow & 0.21 \\
Higlands (>20\%) & 0.26 & Stone layer & 0.26 & Bare ground & 0.28 \\
\hline
\end{tabular}

$$
\mathrm{Cr}=\frac{\sum_{i=1}^{n} C_{i} A_{i}}{\sum_{i=1}^{n} A_{i}}
$$
$\mathrm{A}_{\mathrm{i}} \quad$ : Land area with type of land cover
$\mathrm{C}_{\mathrm{i}} \quad$ : Surface flow coefficient of various types of ground cover
$\mathrm{n} \quad$ : Number of types of ground cover

\subsection{Locations}

The locations of research can be seen in Table 2, which is located in 5 subdistricts in Jakarta Province consist of Jagakarsa, Makasar, Joglo, Tegal Alur and Duri Kosambi (see Figure 5). Each location is representing each category aquifer groundwater level.

Table 2. GOS Sampling locations with aquifer GWL 0-40 meter

\begin{tabular}{|c|c|l|c|}
\hline No & $\begin{array}{c}\text { Categories } \\
\text { Jakarta GWL 0- } \\
\text { 40 meter [19] }\end{array}$ & \multicolumn{1}{|c|}{ GOS Location } & $\begin{array}{c}\text { Area } \\
\text { (ha) }\end{array}$ \\
\hline 1 & Very good & Jagakarsa, Jakarta selatan & \pm 1.1 \\
\hline 2 & Good & Makasar, Jakarta Timur & \pm 1.3 \\
\hline 3 & Moderate & Joglo, Jakarta Barat & \pm 1.1 \\
\hline 4 & Poor & Tegal Alur, Jakarta Barat & \pm 3.1 \\
\hline 5 & Extremely Poor & Duri Kosambi, Jakarta Barat & \pm 1.5 \\
\hline
\end{tabular}




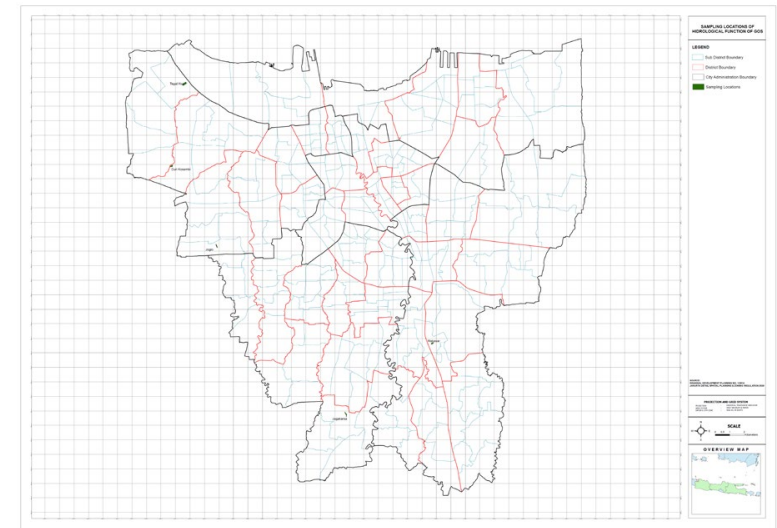

Figure 5. GOS Sampling Locations

\section{Result and discussion}

When the area affected by the 2007 flood event is overlaid with the aquifer groundwater level map, then it can be seen that the "Prone" locations mostly occur in the "Poor" and "Extremely Poor" aquifer category (see in Figure 6). This phenomenon is due to greater land subsidence than areas around and also supports the study that stated one of the caused of land subsidence is by groundwater takes[12].

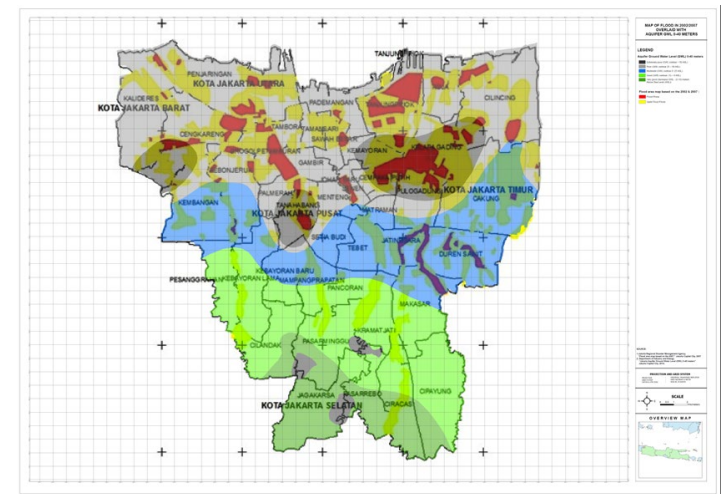

Figure 6. Flood in 2002/2007 overlaid with aquifer GWL 0-40 meter

Besides the location which is historically already a swampy area, Jakarta's target to fulfill $30 \%[25]$ GOS has not yet fulfilled become one of the factors that influence the lack of urban water infiltration so that flood events become increasingly difficult to avoid. 
Based on the GOS sampling location, it was found that not all locations exposed to flood events in 2015 and the biggest flood in 2007. GOS in Makasar and Tegal Alur subdistrict were found to be included in the inundated area, $10-70 \mathrm{~cm}$ at GOS Makassar and $71-150 \mathrm{~cm}$ at GOS Tegal Alur, while the other 3 GOS are in a secure area (see Tabel 3). Table 3 also shows the location of the GOS sampling point for types of land ecoregion.

Table 3. GOS locations and its relation to flood events in $2002 / 2007$ \& 2015

\begin{tabular}{|c|c|c|c|c|c|c|}
\hline No & $\begin{array}{l}\text { Types of } \\
\text { land } \\
\text { ecoregion }\end{array}$ & $\begin{array}{l}\text { Categories } \\
\text { Jakarta } \\
\text { GWL 0-40 } \\
\text { meters [19] }\end{array}$ & GOS location & $\begin{array}{c}\text { Area } \\
\text { (ha) }\end{array}$ & $\begin{array}{l}\text { Flood in } \\
2015[13]\end{array}$ & $\begin{array}{l}\text { Flood in } \\
2007[14]\end{array}$ \\
\hline 1 & $\begin{array}{l}\text { Flood } \\
\text { Plain }\end{array}$ & Very good & $\begin{array}{l}\text { Jagakarsa, Jakarta } \\
\text { selatan }\end{array}$ & \pm 1.1 & Secure & Secure \\
\hline 2 & $\begin{array}{l}\text { Flood } \\
\text { Plain }\end{array}$ & Good & $\begin{array}{l}\text { Makasar, Jakarta } \\
\text { Timur }\end{array}$ & \pm 1.3 & $10-70 \mathrm{~cm}$ & $\begin{array}{l}\text { Quite } \\
\text { flood } \\
\text { prone }\end{array}$ \\
\hline 3 & $\begin{array}{l}\text { Fluvio- } \\
\text { volcanic } \\
\text { Plain }\end{array}$ & Moderate & Joglo, Jakarta Barat & \pm 1.1 & Secure & Secure \\
\hline 4 & $\begin{array}{l}\text { Physical } \\
\text { Plain- } \\
\text { Inter- } \\
\text { Physical } \\
\text { Valley }\end{array}$ & Poor & $\begin{array}{l}\text { Tegal Alur, Jakarta } \\
\text { Barat }\end{array}$ & \pm 3.1 & $71-150 \mathrm{~cm}$ & $\begin{array}{l}\text { Quite } \\
\text { flood } \\
\text { prone }\end{array}$ \\
\hline 5 & $\begin{array}{l}\text { Fluvio- } \\
\text { marin } \\
\text { Plain }\end{array}$ & $\begin{array}{l}\text { Extremely } \\
\text { Poor }\end{array}$ & $\begin{array}{l}\text { Duri Kosambi, Jakarta } \\
\text { Barat }\end{array}$ & \pm 1.5 & Secure & $\begin{array}{l}\text { Quite } \\
\text { flood } \\
\text { prone }\end{array}$ \\
\hline
\end{tabular}

Based on calculations using the Ffolliot equation, the amount of infiltration based on total rainfall (see Table 4) during the last 10 years in each of GOS locations is shown in Table 5 and Figure 7. Although GOS located in 5 locations there are only 4 types of land ecoregion. Three out of four land ecoregions as overall have similar material in general, consisting of ash, sand, and gravel. Because of that in this calculation, the runoff coefficient based on Table 1 used is a merging of 1$)$ the Flat for topography type $(0.03)$; 2) In soil permeability, Sandy Loam soil (0.08) for Plain sandbank beach - Inter-sandbank valley and Clay and Silt (0.16) for flood plain, fluvio-marin plain and fluvio-volcanic plain; 3) Pasture as a vegetation type (0.21). Based on this determination, the value of Cro is 0.32 for Physical Plain-Inter-Physical Valley and 0.4 for Flood Plain, Fluvio-marin Plain and Fluvio-volcanic Plain. 
Table 4. Total Rainfall in 10 years from Meteorology Station Class III Kemayoran - Jakarta Pusat

\begin{tabular}{|c|c|}
\hline Year & $\begin{array}{c}\text { Total Rainfall } \\
(\mathbf{m m} / \text { year })\end{array}$ \\
\hline 2010 & $2,395.00$ \\
\hline 2011 & $1,274.10$ \\
\hline 2012 & $1,488.20$ \\
\hline 2013 & $2,528.10$ \\
\hline 2014 & $2,837.10$ \\
\hline 2015 & $2,086.70$ \\
\hline 2016 & $2,711.50$ \\
\hline 2017 & $2,152.10$ \\
\hline 2018 & $1,501.60$ \\
\hline 2019 & $1,560.00$ \\
\hline
\end{tabular}

Table 5. Infiltration debit at GOS locations in 10 years

\begin{tabular}{|c|c|c|c|c|c|}
\hline \multirow[b]{2}{*}{ Year } & \multicolumn{5}{|c|}{ Infiltration Discharge $\left(\mathrm{m}^{3} /\right.$ year $)$} \\
\hline & $\begin{array}{c}\text { Jagakarsa, } \\
\text { Jakarta selatan }\end{array}$ & $\begin{array}{c}\text { Makasar, } \\
\text { Jakarta Timur }\end{array}$ & $\begin{array}{c}\text { Joglo, } \\
\text { Jakarta Barat }\end{array}$ & $\begin{array}{l}\text { Tegal Alur, } \\
\text { Jakarta Barat }\end{array}$ & $\begin{array}{c}\text { Duri Kosambi, } \\
\text { Jakarta Barat }\end{array}$ \\
\hline 2010 & 16,401 & 18,746 & 15,831 & 50,153 & 21,321 \\
\hline 2011 & 8,705 & 9,949 & 8,402 & 26,618 & 11,316 \\
\hline 2012 & 10,175 & 11,629 & 9,821 & 31,114 & 13,227 \\
\hline 2013 & 17,315 & 19,790 & 16,712 & 52,947 & 22,509 \\
\hline 2014 & 19,437 & 22,215 & 18,761 & 59,436 & 25,267 \\
\hline 2015 & 14,284 & 16,326 & 13,787 & 43,680 & 18,569 \\
\hline 2016 & 18,574 & 21,230 & 17,928 & 56,799 & 24,146 \\
\hline 2017 & 14,733 & 16,839 & 14,221 & 45,053 & 19,153 \\
\hline 2018 & 10,267 & 11,734 & 9,910 & 31,395 & 13,347 \\
\hline 2019 & 10,668 & 12,193 & 10,297 & 32,623 & 13,869 \\
\hline
\end{tabular}


Figure 7. Infiltration discharges $\left(\mathrm{m}^{3} /\right.$ year) at GOS locations in 10 years

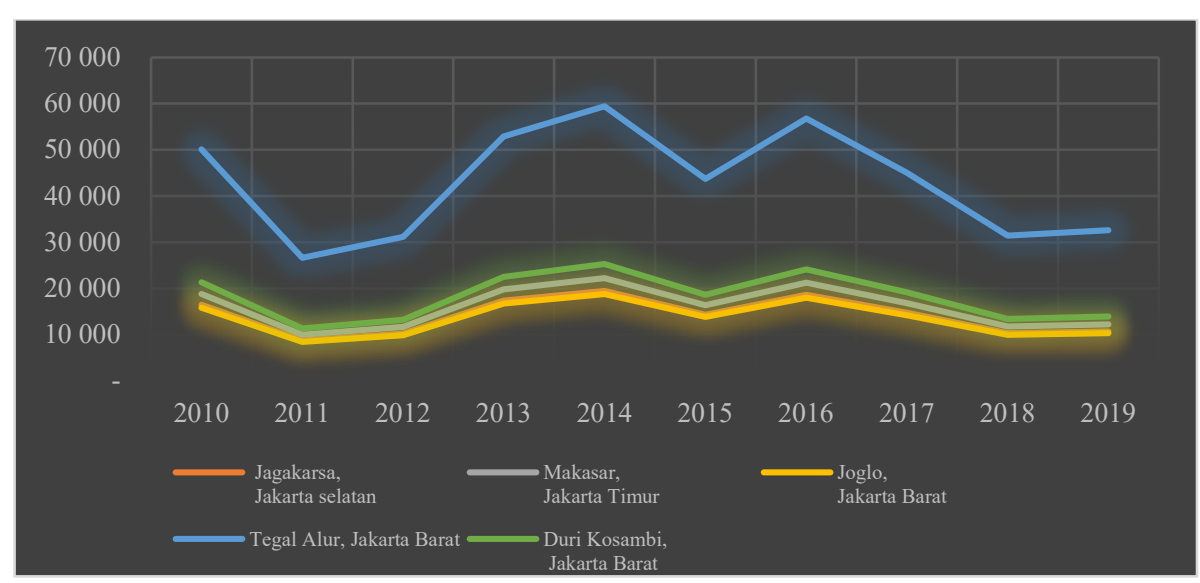

Obtaining the infiltration velocity at each GOS location, the infiltration discharge that already finds should be divided by area (see Table 6). For types of land ecoregion which has the highest infiltration speed every year occurs in Plain sandbank beach - Inter-sandbank valley. The infiltration rate of GWL 0-40 meters shows that the location of GOS with Poor category has the highest infiltration rate.

Table 6. Infiltration velocity at GOS location in 10 years

\begin{tabular}{|c|r|r|r|r|r|}
\hline Year & \multicolumn{6}{|c|}{ Infiltration Velocity $(\mathrm{cm} / \mathrm{s})$} \\
\hline Year & $\begin{array}{c}\text { Jagakarsa, } \\
\text { Jakarta selatan }\end{array}$ & $\begin{array}{c}\text { Makasar, } \\
\text { Jakarta Timur }\end{array}$ & $\begin{array}{c}\text { Joglo, } \\
\text { Jakarta Barat }\end{array}$ & $\begin{array}{c}\text { Tegal Alur, } \\
\text { Jakarta Barat }\end{array}$ & $\begin{array}{c}\text { Duri Kosambi, } \\
\text { Jakarta Barat }\end{array}$ \\
\hline 2010 & $4.5 \mathrm{e}-06$ & $4.5 \mathrm{e}-06$ & $4.5 \mathrm{e}-06$ & $5.2 \mathrm{e}-06$ & $4.5 \mathrm{e}-06$ \\
\hline 2011 & $2.4 \mathrm{e}-06$ & $2.4 \mathrm{e}-06$ & $2.4 \mathrm{e}-06$ & $2.7 \mathrm{e}-06$ & $2.4 \mathrm{e}-06$ \\
\hline 2012 & $2.8 \mathrm{e}-06$ & $2.8 \mathrm{e}-06$ & $2.8 \mathrm{e}-06$ & $3.2 \mathrm{e}-06$ & $2.8 \mathrm{e}-06$ \\
\hline 2013 & $4.8 \mathrm{e}-06$ & $4.8 \mathrm{e}-06$ & $4.8 \mathrm{e}-06$ & $5.4 \mathrm{e}-06$ & $4.8 \mathrm{e}-06$ \\
\hline 2014 & $5.4 \mathrm{e}-06$ & $5.4 \mathrm{e}-06$ & $5.4 \mathrm{e}-06$ & $6.1 \mathrm{e}-06$ & $5.4 \mathrm{e}-06$ \\
\hline 2015 & $4.0 \mathrm{e}-06$ & $4.0 \mathrm{e}-06$ & $4.0 \mathrm{e}-06$ & $4.5 \mathrm{e}-06$ & $4.0 \mathrm{e}-06$ \\
\hline 2016 & $5.1 \mathrm{e}-06$ & $5.1 \mathrm{e}-06$ & $5.1 \mathrm{e}-06$ & $5.8 \mathrm{e}-06$ & $5.1 \mathrm{e}-06$ \\
\hline 2017 & $4.1 \mathrm{e}-06$ & $4.1 \mathrm{e}-06$ & $4.1 \mathrm{e}-06$ & $4.6 \mathrm{e}-06$ & $4.1 \mathrm{e}-06$ \\
\hline 2018 & $2.8 \mathrm{e}-06$ & $2.8 \mathrm{e}-06$ & $2.8 \mathrm{e}-06$ & $3.2 \mathrm{e}-06$ & $2.8 \mathrm{e}-06$ \\
\hline 2019 & $3.0 \mathrm{e}-06$ & $3.0 \mathrm{e}-06$ & $3.0 \mathrm{e}-06$ & $3.4 \mathrm{e}-06$ & $3.0 \mathrm{e}-06$ \\
\hline
\end{tabular}


When Table 4 shows the highest total rainfall occurred in 2014, it was in line with the ability of infiltration that also reach a peak in 2014 at each GOS. Based on the relationship between the classification of ecoregions with infiltration that occurs, the highest infiltration occurs in Plain sandbank beach - Inter-sandbank valley. In this case, it cannot be compared because the area GOS in Plain sandbank beach - Inter-sandbank valley ecoregion is approximately two to three times greater than other GOS in the other ecoregion.

Based on the distribution of 25 points of infiltration locations obtained from GWCO in Figure 6 , the average infiltration velocity value for each category in GWL 0-40 m can be calculated (see Table 6). It is known that the highest infiltration velocity value occurs in the Poor category, while the lowest in the Extremely Poor category

Table 7. The average infiltration velocity in each GWL 0-40 m category

\begin{tabular}{|l|r|r|}
\hline $\begin{array}{c}\text { Categories Jakarta } \\
\text { GWL 0-40 meters }\end{array}$ & $\begin{array}{c}\text { Quantity of } \\
\text { Location }\end{array}$ & $\begin{array}{c}\text { Average Infiltration } \\
\text { velocity (cm/s) }\end{array}$ \\
\hline Extremely Poor & 1 & 0.001 \\
\hline Poor & 11 & 0.013 \\
\hline Moderate & 7 & 0.004 \\
\hline Good & 5 & 0.003 \\
\hline Very Good & 1 & 0.003 \\
\hline \multicolumn{1}{|c|}{ Overall Average } & $\mathbf{2 5}$ & $\mathbf{0 . 0 0 8}$ \\
\hline
\end{tabular}

When average infiltration velocity value is associated with the types of the land ecoregion (see Table 7), Fluvio-marin Plain ecoregion has the highest infiltration velocity value and conversely Flood Plain has the lowest value for infiltration velocity.

Table 8. Average infiltration velocity associated with the types of the land ecoregion

\begin{tabular}{|l|r|r|}
\hline \multicolumn{1}{|c|}{ Types Land Ecoregion } & \multicolumn{1}{c|}{$\begin{array}{c}\text { Quantity of } \\
\text { Location }\end{array}$} & $\begin{array}{c}\text { Average Infiltration } \\
\text { velocity (cm/s) }\end{array}$ \\
\hline Muddy Tidal Plains & 2 & 0.009 \\
\hline Physical Plain and Inter-Physical Valley & 3 & 0.006 \\
\hline Flood Plain & 2 & 0.003 \\
\hline Fluvio-marin Plain & 6 & 0.016 \\
\hline Fluvio-volcanic Plain & 12 & 0.004 \\
\hline \multicolumn{1}{|c|}{ Overall Average } & $\mathbf{2 5}$ & $\mathbf{0 . 0 0 8}$ \\
\hline
\end{tabular}




\section{Conclusion}

Infiltration values obtained in the analysis of this study were obtained in two ways, based on rainfall data calculations and secondary data from GWCO. Based on these sources: first, for the calculation of rainfall data founds that the highest infiltration velocity based on types of the land ecoregion is found in Plain sandbank beach - Inter-sandbank valley while on GWL 0-40 meters located the Poor category. Second, regarding secondary data from GWCO, the highest infiltration velocity value based on types of land ecoregion found in Fluvio-marin Plain, while on GWL 0-40 meters, it is also in the Poor category. The difference in the result of ecoregion types for the highest infiltration velocity values is due to the use of the same soil permeability coefficient for the types of ecoregions of Flood Plain, Fluvio-volcanic Plain, and Fluvio-marin Plain. By obtaining a more detailed worth of the soil permeability coefficient in the next study, it is expected to help the limitations in this study related to the worth of the soil permeability coefficient so a more accurate classification of ecoregion can be determined.

\section{References}

[1] T. Murata and N. Kawai, "Degradation of the urban ecosystem function due to soil sealing: involvement in the heat island phenomenon and hydrologic cycle in the Tokyo metropolitan area," Soil Sci. Plant Nutr., vol. 64, no. 2, pp. 145-155, 2018.

[2] Dinas Kehutanan Provinsi DKI Jakarta, "Master Plan Ruang Terbuka Hijau DKI Jakarta 2018 2038," Jakarta, 2018.

[3] K. Villanueva et al., "Developing Indicators of Public Open Space to Promote Health and Wellbeing in Communities," Appl. Geogr., vol. 57, pp. 112-119, 2015.

[4] United Nations Development Programme, "SDGs GOAL 11: SUSTAINABLE CITIES AND COMMUNITIES," United Nations Development Programme, 2015. [Online]. Available: https://www.undp.org/content/undp/en/home/sustainable-development-goals/goal-11sustainable-cities-and-communities.html. [Accessed: 12-Apr-2019].

[5] J. Van Leeuwen, J. Awad, B. Myers, and D. Pezzaniti, "Introduction to Urban Stormwater : A Global Perspective," Urban Stormwater Flood Manag., pp. 1-28, 2019.

[6] Regional Development Planning, Jakarta Detail Spatial Planning and Zoning Regulation 2030. Indonesia, 2014.

[7] R. Setiowati, "Perumusan Masterplan Ruang Terbuka Hijau Berbasis Pelibatan Para Pihak di Provinsi DKI Jakarta," Sekolah Ilmu Lingkungan Universitas Indonesia, 2019.

[8] Department of Environmental, "Academic Paper of the DKI Jakarta Provincial Environmental Protection and Management Plan," Jakarta Capital City, 2017.

[9] F. Kurniadhini and S. Purnama, "Analisis Potensi Air Tanah untuk Kebutuhan Air Domestik Dan Kepariwisataan di Wilayah Kepesisiran Parangtritis Kabupaten,” J. Bumi Indones., vol. 5, no. 4, 2016.

[10] C. Setiawan, S. Suratman, and M. A. Marfa,i, "Kondisi Sumur Dan Pemodelan Arah Aliran Airtanah Bebas Pada Bentuklahan Fluviomarin Di Jakarta," Jurnal SPATIAL Wahana Komunikasi dan Informasi Geografi, vol. 16, no. 2. p. 1, 2016.

[11] M. Kagabu, R. M. Delinom, R. F. Lubis, J. Shimada, and M. Taniguchi, "Groundwater Characteristics in Jakarta Area, Indonesia,” J. Ris. Geol. dan Pertamb., vol. 20, no. 2, p. 69 , 2010.

[12] H. Z. Abidin, H. Andreas, R. Djaja, D. Darmawan, and M. Gamal, "Land subsidence characteristics of Jakarta between 1997 and 2005, as estimated using GPS surveys," GPS Solut., vol. 12, no. 1, pp. 23-32, 2008. 
[13] Jakarta Regional Disaster Management Agency, "Flood area map based on the 2015 flood event report," Jakarta Capital City, 2015.

[14] Jakarta Regional Disaster Management Agency, "Flood area map based on the 2007," Jakarta Capital City, 2007.

[15] E. Rozos, C. Makropoulos, and Č. Maksimović, "Rethinking urban areas: An example of an integrated blue-green approach," Water Sci. Technol. Water Supply, vol. 13, no. 6, pp. 1534 $1542,2013$.

[16] H. Friana, "Kerugian Akibat Banjir Jakarta Bisa Mencapai 144-220 Miliar," tirto.id, 2018. [Online]. Available: https://irto.id/kerugian-akibat-banjir-jakarta-bisa-mencapai-144-220miliar-cEtp. [Accessed: 07-Oct-2019].

[17] PAM Jaya, “Area Cakupan Pelayanan PAM Jaya," 2019. [Online]. Available: http://pamjaya.co.id/id/service-info/service-coverage. [Accessed: 05-Aug-2019].

[18] F. R. Wahyudi and S. S. Moersidik, "The Analysis of Ground Water Availability and Utility in DKI Jakarta,” Procedia - Soc. Behav. Sci., vol. 227, pp. 799-807, 2016.

[19] Department of Industry and Energy, "Jakarta Aquifer Ground Water Level (GWL) 0-40 meters," Jakarta Capital City, 2014.

[20] Groundwater Conservation Center, "Infiltration and Percolation Level," 2017.

[21] WHO Regional Office for Europe, "Urban green spaces and health," 2016.

[22] Pemerintah Republik Indonesia, Lampiran I Peraturan Menteri Pekerjaan Umum Nomor 12/Prt/M/2014 Tentang Penyelenggaraan Sistem Drainase Perkotaan. Indonesia, 2014

[23] R. Bonita and M. A. Mardyanto, "Studi Water Balance Air Tanah di Kecamatan Kejayan, Kabupaten Pasuruan, Provinsi Jawa Timur,” J. Tek. ITS, vol. 4, no. 1, pp. 21-26, 2015.

[24] L. D'Alberto and G. Lucianetti, "Misinterpretation of the Kenessey method for the determination of the runoff coefficient: a review," Hydrol. Sci. J., vol. 64, no. 3, pp. 288-296, 2019.

[25] Regional Development Planning, Jakarta Spatial Plan 2030. Indonesia, 2012. 